\title{
Atypical injury of radial nerve after humeral shaft fracture
}

\author{
Humerus şaft kırığı sonrası radial sinirin atipik yaralanması
}

\author{
Murat Yeşil, MD, Özal Özcan, MD, Ömer Ali Kaya, MD, Sadık Emre Erginoğlu, MD \\ Department of Orthopedics and Traumatology, Medical Faculty of Afyon Kocatepe University, Afyonkarahisar, Turkey
}

\begin{abstract}
As general opinion, conservative treatment is usually suggested for closed humeral shaft fractures with radial nerve palsy; however, some authors advocate early surgical exploration, particularly for spiral fractures of the humerus accompanied with radial nerve palsy. In this article, we present a case of radial nerve palsy after fracture of the proximal-middle third of humeral shaft. A surgical exploration of the nerve revealed that the sharp tip of the bony fragment at fracture site was penetrated into the nerve and separated the nerve as two bands, almost like a "buttonhole" injury. We think that this kind of an atypical injury of the radial nerve would most probably not recover with conservative management; or the nerve may even be damaged worse by the fragment in case of a possible movement on the nerve's fracture line or by being trapped by callus formation during healing. In this case report, we aimed to raise awareness among orthopedists regarding such and similar atypical injuries of the radial nerve.
\end{abstract}

Keywords: Atypical; fracture; humerus; nerve; palsy; radial.

Fractures involving the humeral shaft, which is defined as the region between the superior border of the pectoralis major insertion and the area immediately above the supracondylar ridge, account for approximately $3 \%$ of all long bone fractures. ${ }^{[1,2]}$ As is widely known, the most common injury associated with closed diaphyseal humeral fracture is the concomitant injury of the radial nerve. ${ }^{[3]}$

The recent literature has suggested that closed fractures are frequently associated with neuropraxia of the radial nerve with spontaneous recovery expected in more than $80 \%$ of cases. On the other hand, open fractures are usually associated with "neurotmesis injury" which is defined as disruption of both the nerve and its sheath and requires early
$\ddot{O Z Z}$

Genel görüş olarak, radial sinir felci bulunan kapalı humerus şaft kırıklarında çoğunlukla konservatif tedavi önerilmektedir, ancak kimi yazarlar özellikle spiral humerus kırığı ile birlikte radial sinir felci bulunması durumunda erken cerrahi eksplorasyonun gerektiğini savunmaktadır. $\mathrm{Bu}$ yazıda humerus cisminin proksimal-orta üçte bir kırığ sonrası bir radial sinir felci olgusu sunuldu. Sinir cerrahi olarak eksplore edildiğinde, kırık sahasında kemik fragmanın keskin ucunun sinire penetre olduğu ve adeta "düğme iliği" yaralanması şeklinde siniri iki bant şeklinde ayırdığı görüldü. Radial sinirin bu tür bir atipik yaralanmasının konservatif izlem ile yüksek olasılıkla iyileşmeyeceği; hatta sinirin kırık hattındaki olası bir oynamada fragman tarafından ya da iyileşme sırasında kallus dokusu tarafından çevrelenerek daha kötü hasarlanabileceği düşünülmektedir. Bu olgu sunumunda radial sinirin bu ve benzeri atipik yaralanmaları konusunda ortopedistler arasında bir farkındalık yaratılması amaçlandı. Anahtar sözcükler: Atipik; kırık; humerus; sinir; palsi; radial.

exploration and repair. ${ }^{[2]}$ Radial nerve palsy can be classified as partial or complete with regard to the extent of physical examination findings. ${ }^{[4]}$

The current literature commonly suggests conservative treatment for most closed humeral shaft fractures with radial nerve palsy; ${ }^{[5]}$ whereas surgical exploration is advocated in cases of open fractures of the humeral shaft associated with radial nerve palsy or when there is no clinical improvement after a period of conservative treatment.

In this case report, we present a case of closed comminuted proximal-middle third humeral shaft fracture with immediate partial radial nerve palsy caused by an atypical buttonhole injury at the fracture site.

- Received: February 23, 2017 Accepted: May 25, 2017

- Correspondence: Murat Yeşil, MD. Afyon Kocatepe Üniversitesi Tıp Fakültesi Ortopedi ve Travmatoloji Anabilim Dalı, 03030 Afyonkarahisar, Turkey. Tel: +90 505 - 4423142 e-mail: drmurat17@hotmail.com 


\section{CASE REPORT}

A 66-year-old female patient was admitted to the emergency department with pain and deformity in her right arm after a slip and fall accident. Physical and radiologic examination revealed a closed comminuted fracture of proximal-middle third humeral shaft with a butterfly fragment (Figures 1, 2). In addition, the patient had symptoms of partial radial nerve injury such as inability of dorsiflexion of the wrist and digits; nevertheless, she had normal sensation on the dorsolateral aspect of the hand and the dorsal aspect of the radial thumb, second and third fingers digits. Eventually, the patient was diagnosed with comminuted proximal-middle third humeral shaft fracture and concomitant partial nerve palsy. ${ }^{[4]}$ Thereafter, the patient was hospitalized and observed for routine trauma care. A written informed consent was obtained from the patient.

The patient had a 12-B2 type fracture according to the Arbeitsgemeinschaft für Osteosynthesefragen/ Orthopaedic Trauma Association (AO/OTA) classification of diaphyseal humeral fractures which designates the humerus in three parts: proximal, diaphyseal and distal, and PM-I type fracture (P and $\mathrm{M}$ stand for proximal and middle third of humeral shaft and the letter I for intermediate fractures with one or two sizable bony fragments) according to a more recent classification system reported by Garnavos et al. ${ }^{[6]}$ The pros and cons of these systems

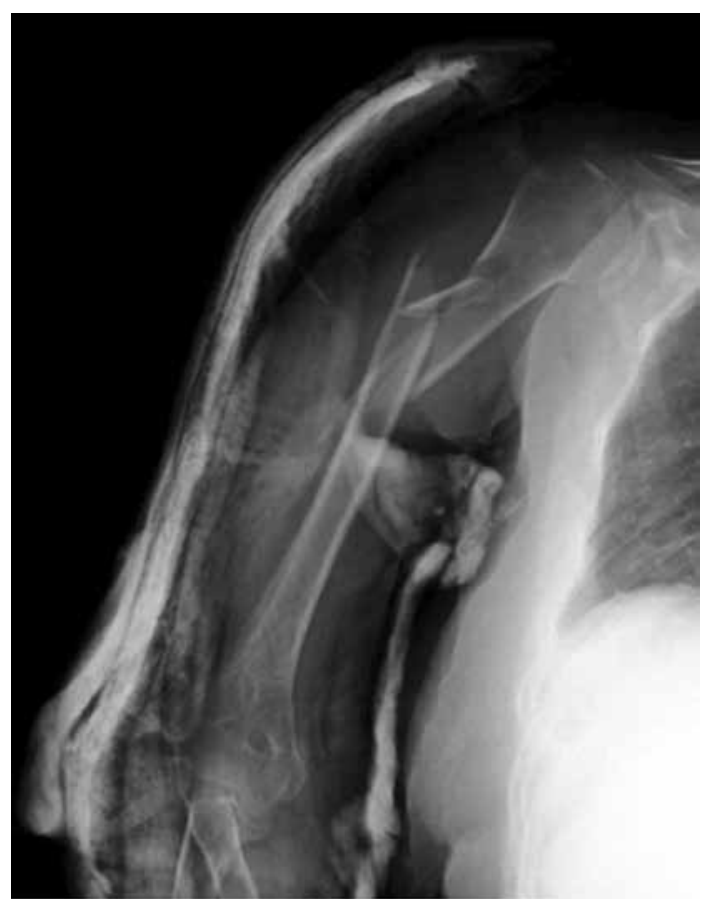

Figure 1. Plain radiograph demonstrating proximalmiddle third humeral shaft fracture. in the choice of treatment method will be discussed later.

At this point, surgical intervention was a fundamental decision to make; and it will be discussed thoroughly in the following section. After reevaluation of the patient, review of the literature and a challenging decision-making process for the surgical team, our preference for treatment was open reduction and internal fixation of the humeral shaft fracture with exploration of the radial nerve. Thereafter, the patient was informed about all treatment options and complications prior to surgery.

Since the humeral fracture was located in proximal-middle third of the humeral shaft, an extended deltopectoral approach was used. During the approach, the radial nerve was identified and dissected on its course through the fracture site. At the fracture site, the nerve was found to have a unique type of injury; penetration of the bony spike of the humeral fracture through the body of the radial nerve, mimicking a "buttonhole injury". The nerve was immediately set free from the bony spike and explored (Figures 3, 4). We decided not to perform any surgical repair at that time, since the $2.5-3 \mathrm{~cm}$ long longitudinal laceration injury left most of the fibers intact. The fracture was reduced and fixated with an anatomical proximal humerus plate (Figure 5).

At the six-month follow-up visit, all sensory and motor functions of the nerve were fully recovered. In addition, radiographs demonstrated good healing at the fracture site (Figures 6, 7).

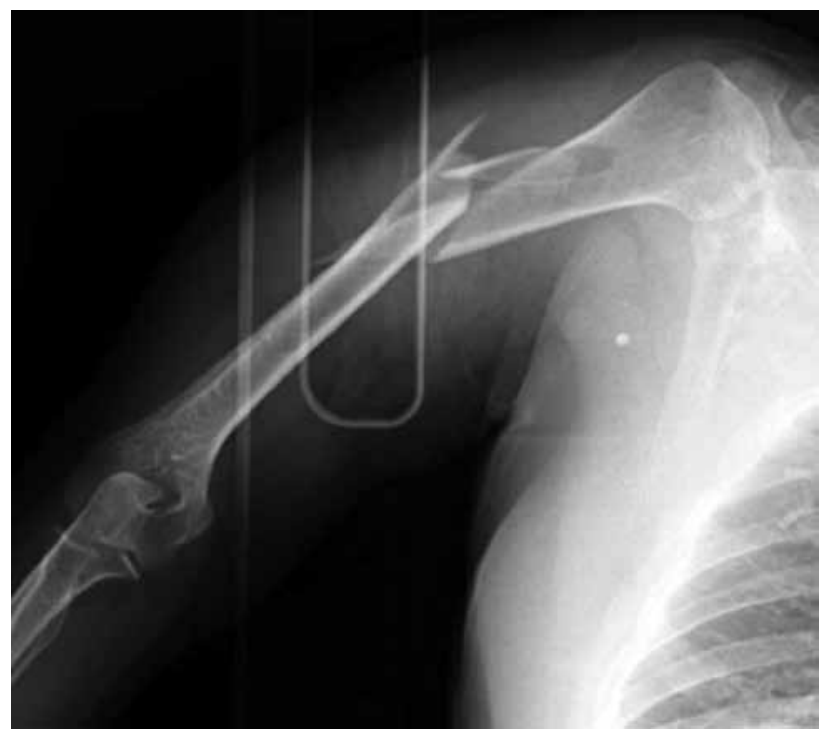

Figure 2. Plain radiograph demonstrating proximal-middle third humeral shaft fracture. 


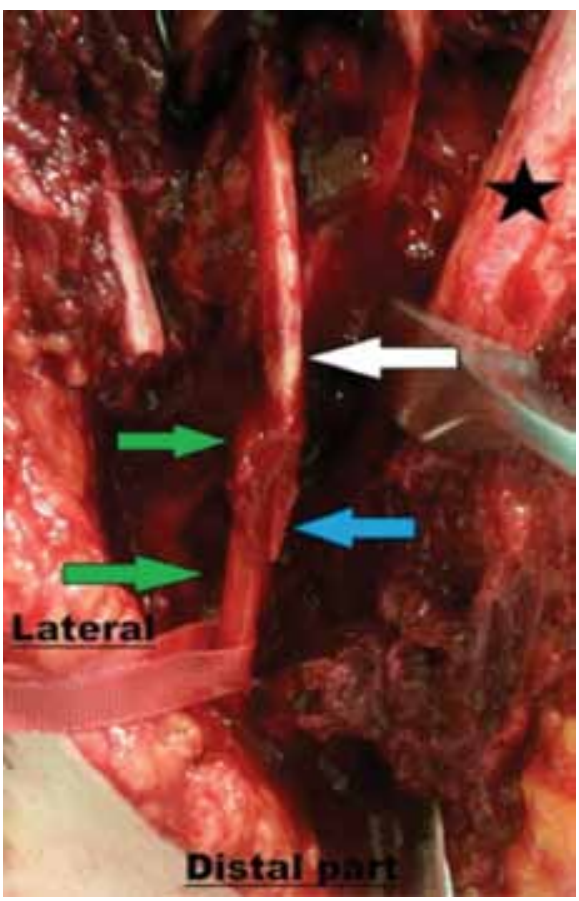

Figure 3. Bony spike penetrating into the corpus of nerve and dividing nerve into two intact slips mimicking a "buttonhole injury". Green arrow: Radial nerve; White arrow: Bony fragment; Blue arrow: Knifelike tip of bony fragment penetrating into nerve; $\star$ Distal humeral shaft angulated to expose nerve.

\section{DISCUSSION}

The radial nerve is the most frequently injured nerve in the upper limb, especially in humeral fractures, because of its close proximity to the bone during its course. ${ }^{[7]}$ The vast majority of closed humeral fractures are treated nonoperatively since union rates are up to $90 \%$ in these cases. For cases ending with malunion, up to $20^{\circ}$ anterior angulation or $30^{\circ}$ varus angulation are generally well tolerated in the arm. Therefore, functional bracing is widely accepted as the mainstay of the treatment for closed humerus fractures. ${ }^{[8-10]}$

The recent literature presents an approximate rate of $11 \%$ for radial nerve palsy after closed humeral shaft fractures; on the other hand, systemic reviews report that $70 \%$ of these cases show spontaneous recovery of nerve functions after three or six months from the time of injury. ${ }^{[1]}$ Herein, the surgeon has to reckon with a difficult preference of "whether or not to perform surgery" in patients with partial radial nerve deficit without any absolute surgical indication for fixation of the fracture. Although there are some previously reported recommendations such as; "if radial nerve dysfunction is concurrent with spiral and comminuted humeral fracture, early exploration may be beneficial in terms of early identification of

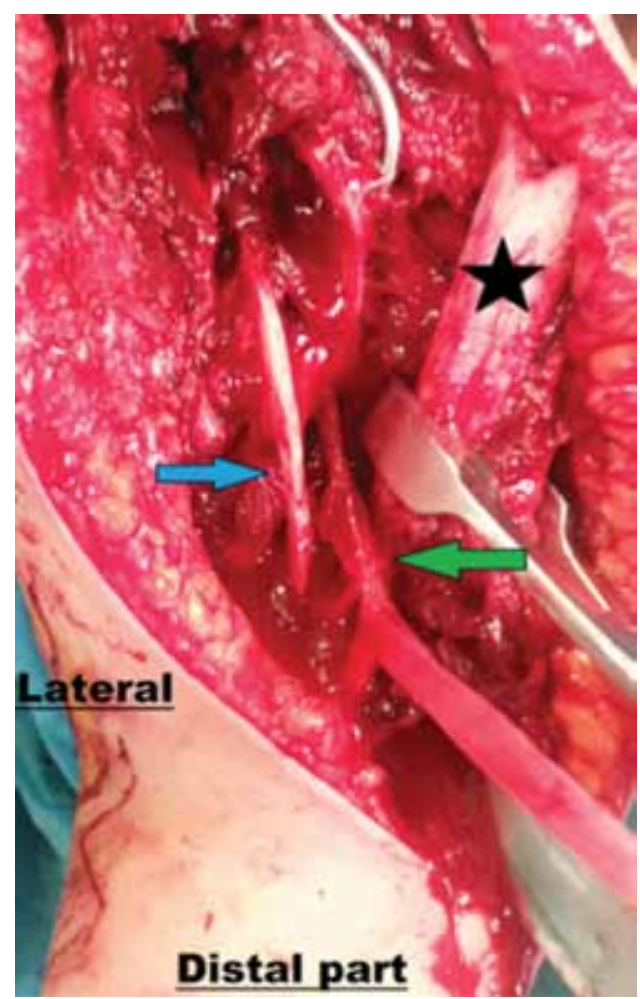

Figure 4. Nerve was set free from bony spike. Blue arrow: Bony spike; Green arrow: Radial nerve; $\star$ Distal humeral shaft angulated to expose nerve.

nerve injury", ${ }^{[12]}$ it is still a matter of debate as to what should be done for cases with no distinct indications for surgery.

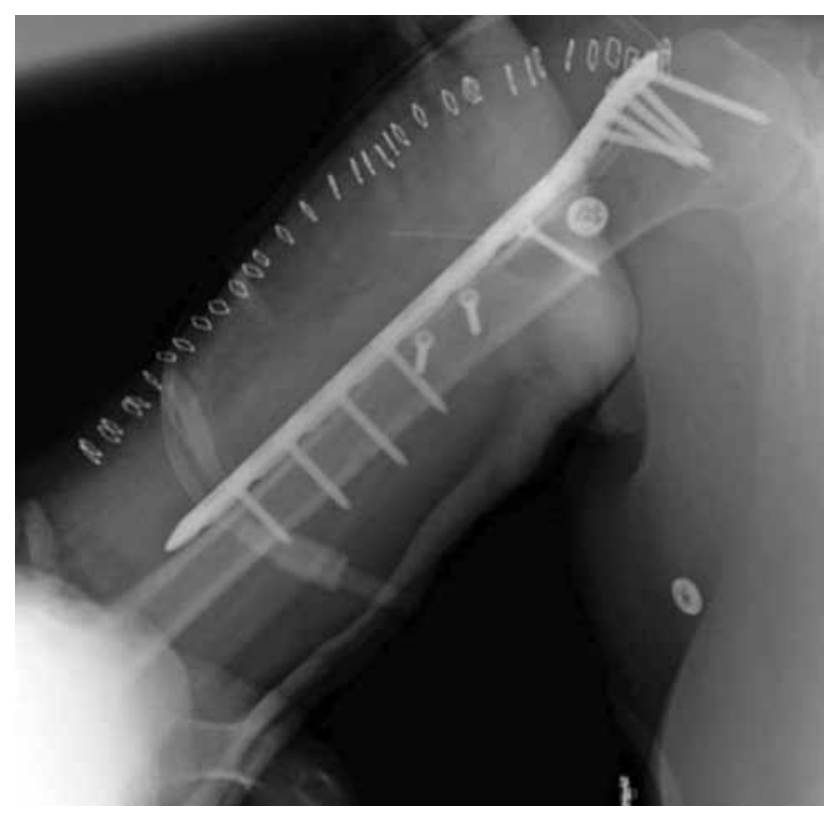

Figure 5. Plain radiograph showing reduction and fixation with an anatomical proximal humerus plate. 


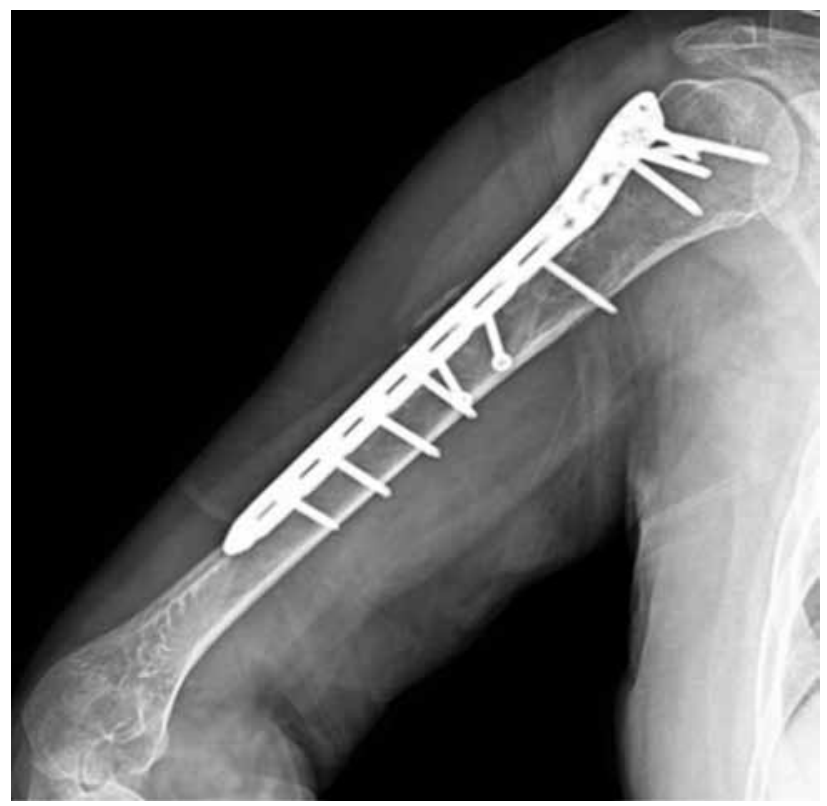

Figure 6. Plain anteroposterior radiograph showing good healing at fracture site.

As mentioned before, we had to decide about the choice of treatment method. First of all, neither long oblique fracture extending to the proximal humerus nor partial radial nerve palsy were indications for operative management of diaphyseal humeral fractures. ${ }^{[13]}$ Moreover, proximal third, long oblique fracture was a relative indication for nonoperative management of diaphyseal humeral fractures. ${ }^{[13]}$ Thus, there were both nonoperative and operative options available regarding the basic orthopedic knowledge.

A renowned essential step in decision-making is an accurate classification of the fracture. A widely used system for classification of long bone fractures is AO/OTA, which was presented in 1990. ${ }^{[13]}$ Our patient had a 12-B2 type fracture according to AO/OTA classification. AO/OTA classification, although it is widely known and used, has received criticism for having low inter- and intra-observer variation agreement and reliability. ${ }^{[14]}$ We experienced the same issue while classifying our patient's fracture since it involved two zones of the humeral shaft: proximal and middle third. According to a recent classification by Garvanos et al., ${ }^{[6]}$ which is a supplementation of the AO/OTA classification, the patient had PM-I type humeral shaft fracture. In this system, the letters $\mathrm{P}$ and $\mathrm{M}$ stand for proximal and middle third of humeral shaft and the letter I for intermediate fractures with one or two sizable bony fragments. Garnavos et al. ${ }^{[6]}$ reported that fractures extending to multiple zones like PM type and presence of

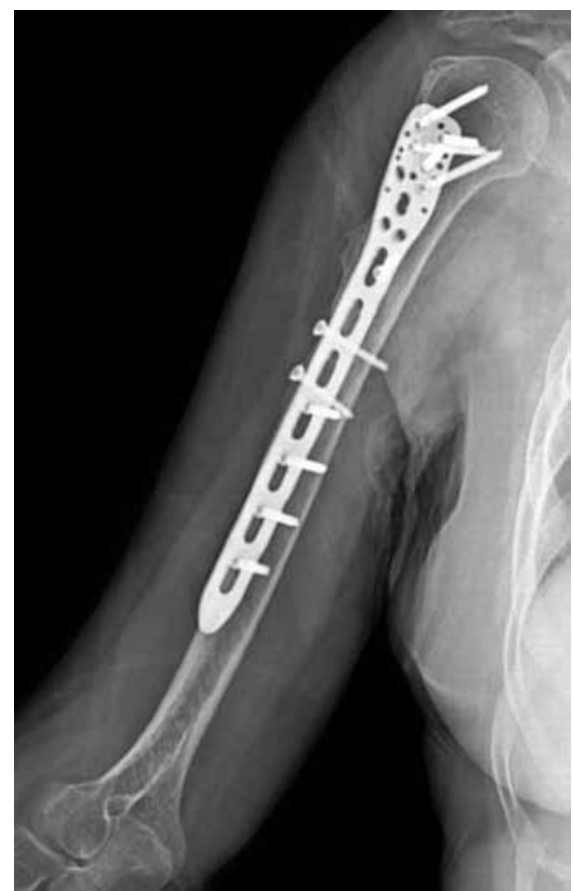

Figure 7. Plain lateral radiograph showing good healing at fracture site.

intermediate morphology were all negative factors for fracture healing. From this point of view, Toivanen et al. ${ }^{[15]}$ also reported a high rate of nonunion (54\%) after conservative treatment when the fracture was located at the proximal third of the diaphysis. Similarly, Ekholm et al. ${ }^{[16]}$ reported that "despite good overall results achieved with conservative treatment of humeral shaft fractures", there is a trend toward an increased number of nonunions in patients with OTA type A fractures involving the proximal zone.

Basic anatomic knowledge dictates that a serious injury of the radial nerve, such as rupture, at this level (proximal-middle shaft of humerus) would involve total palsy with both motor and sensory dysfunction. Therefore, we thought that the partial radial nerve palsy with this fracture would be neuropraxia, which is expected to recover spontaneously in most cases. At this point, a good choice might be to conduct an early electrophysiological evaluation for the nerve; however, recent studies have reported that the nerve and muscles can exhibit the first signs of recovery only about one month before clinical recovery. ${ }^{[13]}$ Since recovery of nerve conduction is usually not evident much earlier than clinical recovery, it is not as helpful in making the decision for exploration of the nerve. Another preference in these cases could be ultrasound evaluation as an imaging modality that might guide surgical decision-making. In experienced hands, 
ultrasonography can detect compression of the nerve as well as discontinuity of the nerve. ${ }^{[13]}$ However, it is a highly user-dependent technique and may not be as successful as desired at diagnosing radial nerve discontinuity. Hence, we did not use any of these modalities because of their limited success.

To elucidate, alongside the Garnavos classification and previous reports in the literature, our own experience of similar cases indicated that conservative treatment in this particular case could not guarantee proper healing of the fracture. Therefore, after a certain decision making process, we decided to perform an open reduction and internal fixation concurrent with exploration of the radial nerve.

In this case, the fracture pattern of the humerus mostly affected our decision to treat the humeral shaft fracture with open reduction and internal fixation. If the patient had a different fracture pattern, such as OTA type B or simple fracture, we would likely decide nonoperative treatment without exploration and identification of radial nerve and misdiagnose this rare type of injury. In addition, the bony spike could jeopardize the nerve subsequent to major movements or callus formation could trap the nerve resulting in unsuccessful recovery of nerve functions. During the surgery, after the nerve was released from the bony spike (Figure 2), the surgical team decided not to perform any surgical repair. At the six-month follow-up visit, all sensory and motor functions of the nerve were fully recovered.

Although nonoperative treatment of closed humeral fractures leads to spontaneous radial nerve recovery in the majority of cases, it is undeniable that there are still some cases in which atypical injuries of the radial nerve may remain undiagnosed if they are treated nonoperatively. Unfortunately, current diagnostic modalities such as electrophysiological evaluation and ultrasound imaging are not fully capable of detecting atypical injuries, which can consequently jeopardize a full recovery of the radial nerve. We think that this kind of rare injury of the radial nerve would not recover with a strategy of expectant management; or even worse, it could be trapped in callus formation during bone healing. Another objective of this case report is to act as a reminder of this kind of rare injury, which may create pitfalls for treatment.

As orthopedic surgeons, despite a growing mass of knowledge, we sometimes have to rely on experience and clinical signs including injury mechanism and subtle clues in order to find our own path in treating patients. This case reminded us of a famous quotation by Fischer: The patient does not care about your science; what he wants to know is, can you cure him?

\section{Declaration of conflicting interests}

The authors declared no conflicts of interest with respect to the authorship and/or publication of this article.

\section{Funding}

The authors received no financial support for the research and/or authorship of this article.

\section{REFERENCES}

1. Carroll EA, Schweppe M, Langfitt M, Miller AN, Halvorson JJ. Management of humeral shaft fractures. J Am Acad Orthop Surg 2012;20:423-33.

2. DeFranco MJ, Lawton JN. Radial nerve injuries associated with humeral fractures. J Hand Surg Am 2006;31:655-63.

3. Ekholm R, Adami J, Tidermark J, Hansson K, Törnkvist $\mathrm{H}$, Ponzer S. Fractures of the shaft of the humerus. An epidemiological study of 401 fractures. J Bone Joint Surg Br 2006;88:1469-73.

4. Niver GE, Ilyas AM. Management of radial nerve palsy following fractures of the humerus. Orthop Clin North Am 2013;44:419-24.

5. Prodromo J, Goitz RJ. Management of radial nerve palsy associated with humerus fracture. J Hand Surg Am 2013;38:995-8.

6. Garnavos C, Kanakaris NK, Lasanianos NG, Tzortzi P, West RM. New classification system for long-bone fractures supplementing the AO/OTA classification. Orthopedics 2012;35:709-19.

7. Bumbasirevic M, Palibrk T, Lesic A, Atkinson H. Radial nerve palsy. EFORT Open Rev 2017;1:286-294.

8. Pehlivan O, Rodop O, Kiral A, Kuskucu SM, Gudemez E, Kaplan H. Functional treatment of humeral shaft fractures. Eklem Hastalik Cerrahisi 2000;11:45-51.

9. Muratlı HH, Yüksel HY, Çelebi L, Dağlı C, Biçimoğlu A. Functional treatment of humeral fractures in adults. Eklem. Hastalik Cerrahisi 2004;15:143-51.

10. Pehlivan O, Arpacioglu OM, Kiral A, Akmaz İ, Mahirogullari $\mathrm{M}$, Kaplan H. Comparison between functional bracing and locked intramedullary nailing in isolated and closed humeral shaft fractures. Eklem Hastalik Cerrahisi 2005;16:175-80.

11. Shao YC, Harwood P, Grotz MR, Limb D, Giannoudis PV. Radial nerve palsy associated with fractures of the shaft of the humerus: a systematic review. J Bone Joint Surg $\mathrm{Br}$ 2005;87:1647-52.

12. Yörükoğlu AÇ, Demirkan AF, Büker N, Akman A, Ok N. Humeral shaft fractures and radial nerve palsy: early exploration findings. Eklem Hastalik Cerrahisi 2016;27:41-5.

13. Garnavos C. Humeral shaft fractures. In: Court-Brown $C M$, Heckman JD, McQueen MM, Ricci WM, Tornetta P, McKee MD, editors. Rockwood and Green's fractures in adults. Eighth Edition. Philedelphia: Wolters Kluwer Health; 2015. p. 1287-340.

14. Swiontkowski MF, Agel J, McAndrew MP, Burgess AR, MacKenzie EJ. Outcome validation of the AO/OTA fracture classification system. J Orthop Trauma 2000;14:534-41.

15. Toivanen JA, Nieminen J, Laine HJ, Honkonen SE, Järvinen MJ. Functional treatment of closed humeral shaft fractures. Int Orthop 2005;29:10-3.

16. Ekholm R, Tidermark J, Törnkvist H, Adami J, Ponzer S. Outcome after closed functional treatment of humeral shaft fractures. J Orthop Trauma 2006;20:591-6. 